\title{
PUSAT PENCEGAHAN CYBERBULLYING: PENCEGAHAN CYBERBULLYING MELALUI KARYA ARSITEKTUR
}

\author{
Brian James ${ }^{1)}$, Doddy Yuono ${ }^{21}$ \\ 1)Program Studi S1 Arsitektur, Fakultas Teknik, Universitas Tarumanagara, brianjameswijaya@gmail.com \\ 2) Program Studi S1 Arsitektur, Fakultas Teknik, Universitas Tarumanagara, masdoddyuono@gmail.com
}

\begin{abstract}
Abstrak
Pesatnya perkembangan teknologi, menciptakan gap yang sangat besar pada generasi sebelumnya. Ditandai dengan adanya internet yang memudahkan para pengguna dapat saling berinteraksi tanpa batas. Selama berinteraksi di internet, seseorang cenderung lebih terbuka untuk mengespresikan dirinya tanpa harus terbentur norma-norma sosial yang biasa ditemukan pada interaksi langsung. Hal ini membawa pengaruh yang sangat besar pada generasi milenial yang ditandai dengan munculnya fenomena efek disinhibisi online/online disinhibition effects, disinhibisi merupakan suatu ketiadaan batas dalam berkomunikasi, dimana online user dapat lebih terbuka dan mengekspresikan emosinya secara personal dengan sesama online user yang baru dikenal. Menurut Suler (2004), aktivitas seperti ini disebut dengan benign disinhibition atau disinhibisi yang tidak berbahaya, membuat Generasi Millennial mudah menggunakan kata-kata kasar, kritik yang kejam, kemarahan, kebencian, bahkan ancaman terhadap orang lain. Selain itu ditambah juga mereka yang mengunjungi sisi gelap internet seperti website pornografi, kriminal atau kekerasan yaitu aktivitas yang merupakan sebagai toxic disinhibition atau disinhibisi yang berbahaya (Suler, 2004). Meningkatnya tindakan cyberbullying di kota, menjadi faktor utama bagi perancang untuk merancang pusat pencegahan cyberbullying, sebagai wadah edukasi baru dengan penggunaan Virtual Reality, sebagai bentuk simulasi dampak cyberbullying dengan harapan terciptanya kesadaran dan partisipasi publik bagi para remaja dan orang dewasa atas bahaya Cyberbullying, untuk saling bertukar pikiran dalam bentuk Community Center.
\end{abstract}

Kata Kunci: Community Center; Cyberbullying; Disinhibisi Online; Virtual Reality

\begin{abstract}
The rapid development of technology created a huge gap in the previous generation. Marked by the existence of the internet that facilitates users to communicate with each other without limits. While communicating on the internet, someone who is more open to express himself without having to hit social norms is commonly found indirect interaction. This has a huge influence on the millennial generation which is characterized by the phenomenon of online disinhibition effects / online disinhibited effects, disinhibition is an absence of boundaries in conversations, where online users can access and use their emotions personally with newly recognized online users. According to Suler (2004), activities such as these are called benign or disinhibited disinhibitions that are harmless, making Millennials easily use harsh words, cruel, challenging, hateful, even opposing criticism. In addition, they are also added to those released from dangerous internet sites such as pornographic sites, crime or violence are activities that contain toxic or disinhibition that is dangerous (Suler, 2004). Increasing cyberbullying in the city has become a major factor for designers to progressively cyberbullying, as a new educational forum using Virtual Reality, as a form of simulation to counter cyberbullying in the hope of creating public interest and participation for teenagers and cyberbullying people, exchange ideas in the form of a Community Center.
\end{abstract}

Keyword: Community Center; Cyberbullying; Online Disinhibition; Virtual Reality 


\section{PENDAHULUAN}

Generasi yang sebagian besar dikenal lahir pada tahun 1980 hingga 2000 atau yang biasa kita sebut Generasi Millennial ini, merupakan salah satu generasi yang sangat berpengaruh terhadap perkembangan teknologi masa kini, namun juga generasi yang sangat tergantung dan dipengaruhi oleh perkembangan teknologi. Tingkat pendidikan tinggi yang dimiliki sebagian besar generasi millennial secara perlahan menciptakan perubahan dan pengaruh besar dalam hidup mereka. hal ini menunjukan bahwa semakin tinggi pengetahuan manusia akan ilmu pengetahuan, maka akan semakin tinggi pula perkembangan teknologi yang akan diciptakan oleh manusia.

Perkembangan teknologi memang sangat diperlukan untuk menciptakan sesuatu yang baru dan berguna bagi kehidupan manusia, namun tentu saja setiap hal yang baru memberikan dampak positif dan negatif. Namun kecanggihan teknologi secara langsung maupun tidak langsung dapat mempengaruhi perkembangan perilaku manusia bagi sebagian besar generasi millennial. Pesatnya perkembangan teknologi ini telah menarik perhatian dari seorang futuris terkenal Ray Kurzweil, ia berpendapat bahwa kemampuan manusia yang terus meningkat dalam mengembangkan teknologi, akan membawa perubahan yang sangat besar sehingga dapat mempengaruhi kesadaran manusia sebagai makhluk sosial.

Asosiasi Penyelenggara Jasa Internet indonesia mengungkapkan peningkatan yang luar biasa pada tahun 2014 atas kerjasama dengan pihak Pus Pusat Kajian Komunikasi (PusKaKom), disebutkan bahwa pengguna internet di Indonesia kini telah mencapai angka 88,1 juta. Sesuai dengan jumlah populasi penduduk Indonesia yang menurut data Badan Pusat Statistik (BPS) mencapai 252,5 juta jiwa, maka pengguna internet di Indonesia mengalami pertumbuhan 16,2 juta jiwa dari total 71,9 juta pengguna di tahun 2013 lalu. Usia pengguna internet di Indonesia terdapat pada usia 18-25 tahun atau 49\% (APJII, 2014). Pesatnya perkembangan teknologi, menciptakan gap yang sangat besar pada generasi sebelumnya. Ditandai dengan adanya internet yang memudahkan para pengguna dapat saling berinteraksi tanpa batas. Selama berinteraksi di internet, seseorang cenderung lebih terbuka untuk mengespresikan dirinya tanpa harus terbentur norma-norma sosial yang biasa ditemukan pada interaksi langsung. Fenomena ini disebut efek disinhibisi online/online disinhibition effects, dimana online user dapat lebih terbuka dan mengekspresikan emosinya secara personal dengan sesama online user yang baru dikenal. Menurut Suler (2004), aktivitas seperti ini disebut dengan benign disinhibition atau disinhibisi yang tidak berbahaya.

$\mathrm{Hal}$ ini membuat generasi milenial yang hidup diskesejamanan ini sangat berbeda dengan generasi baby boomers. Dimana sifat benign disinhibition tersebut membuat generasi milenial mudah menggunakan kata-kata kasar, kritik yang kejam, kemarahan, kebencian, bahkan ancaman terhadap orang lain. Selain itu ditambah juga mereka yang mengunjungi sisi gelap internet seperti website pornografi, kriminal atau kekerasan yaitu aktivitas yang merupakan sebagai toxic disinhibition atau disinhibisi yang berbahaya menurut Suler (2004). Aktivitas toxic disinhibition pada generasi milenial ini membuat mereka secara tidak langsung lebih mudah untuk melakukan tindakan cyberbullying yang mempengaruhi perilaku mereka dan merugikan orang lain.

Lambat laun cyberbullying akan terus menggrogoti kesehatan mental remaja, dan dampak jangka panjang yang merusak perilaku generasi millenial. Untuk membangun kembali perilaku kesehatan mental remaja dan mencegah aktivitas cyberbullying, arsitketur berperan penting sebagai wadah sebuah program atau sistem yang mendukung pendidikan dalam proses kedewasaan moral yang dapat memupuk perilaku berdasarkan norma-norma sosial yang dapat meningkatkan kepedulian sosial individu.

Didasari oleh karakteristik remaja yang masih membutuhkan arahan dan bimbingan dalam hidupnya, arsitektur dapat berperan penting dalam keterlibatan remaja terhadap cyberbullying. Remaja yang memiliki kedekatan dengan orang yang lebih dewasa dapat mengurangi kecenderungan anak terlibat dalam cyberbullying (Willard, 2005). Orang dewasa 
yang terus memantau kegiatan online anak dapat memberikan suatu batasan bagi anak dalam berinteraksi secara online sehingga mereka akan berpikir dua kali untuk terlibat dalam forum atau interaksi yang memungkinkan terjadinya cyberbullying. Oleh karena itu sebagai institusi seni, menjadi wadah pameran yang digunakan untuk merasakan situasi intimidasi yang dihadapi korban cyberbullying untuk bersama-sama membangun rasa kepedulian sosial dan mengubah aktivitas penindasan menjadi sebuah peninggalan sejarah.

\section{KAJIAN LITERATUR}

\section{Generasi Milenial}

Generasi milenial atau biasa disebut generasi Y lahir pada rentang tahun 1980 hingga 2000 ini merupakan asset masa depan bangsa Indonesia, diperkirakan pada tahun 2030, mayoritas usia produktif akan dikuasai generasi milenial sebesar $70 \%$. Berdasarkan hasil survey BPS (badan pusat statistik), populasi penduduk negara-negara kawasan asia tenggara, Indonesia menjadi kunci jumlah penduduk produktif terbanyak. Dari 10 negara anggota ASEAN diperkirakan jumlah penduduk mencapai 625 juta dan $23 \%$ nya adalah generasi milenial dari Indonesia.

Generasi milenial ini, merupakan salah satu generasi yang sangat berpengaruh terhadap perkembangan teknologi masa kini, namun juga generasi yang sangat tergantung dan dipengaruhi oleh perkembangan teknologi. Kecanggihan teknologi secara langsung maupun tidak langsung dapat mempengaruhi perkembangan moral. Seseorang dapat berperilaku buruk akibat penggunaan teknologi yang tidak pada tempatnya. Efek dari Kecanggihan teknologi tersebut dapat kita rasakan dalam kehidupan sehari-hari. Menghilangnya norma dan nilai serta sopan santun yang ada di masyarakat akibat pengaruh teknologi membuat generasi muda tidak lagi mengindahkan moral yang ada di Indonesia.

Pesatnya perkembangan teknologi, menciptakan gap yang sangat besar pada generasi sebelumnya. Ditandai dengan adanya internet yang memudahkan para pengguna dapat saling berinteraksi tanpa batas. Selama berinteraksi di internet, seseorang cenderung lebih terbuka untuk mengespresikan dirinya tanpa harus terbentur norma-norma sosial yang biasa ditemukan pada interaksi langsung. Fenomena ini disebut efek disinhibisi online/online disinhibition effects, dimana online user dapat lebih terbuka dan mengekspresikan emosinya secara personal dengan sesama online user yang baru dikenal. Menurut Suler (2004), aktivitas seperti ini disebut dengan benign disinhibition atau disinhibisi yang tidak berbahaya.

Dimana sifat benign disinhibition tersebut membuat generasi milenial mudah menggunakan kata-kata kasar, kritik yang kejam, kemarahan, kebencian, bahkan ancaman terhadap orang lain. Selain itu ditambah juga mereka yang mengunjungi sisi gelap internet seperti website pornografi, kriminal atau kekerasan yaitu aktivitas yang merupakan sebagai toxic disinhibition atau disinhibisi yang berbahaya menurut Suler (2004). Aktivitas toxic disinhibition pada generasi milenial ini membuat mereka secara tidak langsung lebih mudah untuk melakukan tindakan cyberbullying yang mempengaruhi perilaku mereka dan merugikan orang lain.

\section{Cyberbullying}

Cyberbullying adalah segala bentuk kekerasan yang dialami anak atau remaja dan dilakukan teman seusia mereka melalui dunia maya atau internet. Cyberbullying merupakan kejadian seorang anak atau remaja diejek, dihina, diintimidasi, atau dipermalukan oleh anak atau remaja lain melalui media internet, teknologi digital atau telepon seluler (Choria Y, 2014). Dari hasil survey yang dilaksanakan beberapa waktu yang lalu tercatat sebanyak $97 \%$ responden yang mempunyai akun Twitter atau Facebook. Sebanyak 46\% responden pernah berada dalam pertengkaran online dan $6 \%$ diantaranya berada dalam pertengkaran online lebih dari 5 kali. 
Umumnya terdapat 3 elemen baik dalam setiap praktek bullying dan cyberbullying, yaitu: Pelaku (bullies), Korban (victims) dan Saksi peristiwa (bystander). Beberapa jenis dari cyberbullying yang dilakukan oleh pelaku sebagai berikut:

a. Flaming: yaitu mengirimkan pesan teks yang isinya merupakan kata-kata yang penuh amarah dan frontal. Istilah "flame" ini pun merujuk pada kata-kata pesan yang berapi-api.

b. Harassment (gangguan): pesan-pesan yang berisi gangguan yang menggunakan email, sms, maupun pesan teks di jejaring sosial dilakukan secara terus menerus.

c. Denigration (pencemaran nama baik): yaitu proses mengumbar keburukan seseorang di internet dengan maksud merusak reputasi dan nama baik orang tersebut.

d. Impersonation (peniruan): berpura-pura menjadi orang lain dan mengirimkan pesan-pesan atau status yang tidak baik.

e. Outing: menyebarkan rahasia orang lain, atau foto-foto pribadi orang lain.

f. Trickery (tipu daya): membujuk seseorang dengan tipu daya agar mendapatkan rahasia atau foto pribadi orang tersebut.

g. Exclusion (pengeluaran): secara sengaja dan kejam mengeluarkan seseorang dari grup online.

h. Cyberstalking: mengganggu dan mencemarkan nama baik seseorang secara intens sehingga membuat ketakutan besar pada orang tersebut (Jalil A, 2015).

\section{Faktor-Faktor Penyebab Terjadinya Cyberbullying}

\section{Bullying}

Penelitian dilakukan oleh Ingke (2010) menunjukan bahwa dari keseluruhan responden pernah terlibat dalam tindakan bullying baik menjadi korban ataupun pelaku, sedangkan responden yang terlibat dalam tindakan cyberbullying sebanyak $82,55 \%$ berasal dari remaja berusia $12-15$ tahun. hal ini menunjukan bahwa $\pm 82,55 \%$ generasi milenial yang berusia $21-24$ tahun pernah menjadi korban dan pelaku cyberbullying.

Karakteristik Kepribadian

Karakteristik anak yang menjadi pelaku bullying seperti yang dipaparkan oleh Camodeca \& Goossens (2005; Kowalski, et al., 2008) adalah sebagai berikut:

a Memiliki kepribadian yang dominan dan senang melakukan kekerasan.

b Cenderung temperamental, impulsif, dan mudah frustasi.

c Memiliki sikap positif terhadap kekerasan dibandingkan anak lainnya.

d Kesulitan mengikuti peraturan.

e Terlihat kuat dan menunjukan sedikit rasa empati atau belas kasihan kepada korban cyberbullying.

f Sering bersikap secara agresif terhadap orang dewasa.

g Pandai berkelit pada situasi sulit.

h Terlibat dalam agresi proaktif (seperti agresi yang disengaja untuk meraih tujuan tertentu) dan agresi reaktif (seperti reaksi defensive ketika diprovokasi).

Sedangkan karakteristik mayoritas korban cyberbullying (Demeray \& Brown, 2009; Marden, 2010) adalah:

a. Remaja yang kemampuan pengetahuannya masih belum cukup untuk membuat keputusan secara efektif.

b. Remaja yang memiliki orang tua yang protektif berlebih namun cenderung memiliki hubungan teman sebaya yang sehat dan memiliki nilai-nilai yang bagus.

c. Remaja yang hubungan dengan orangtuanya dan/atau teman sebayanya sedang melemah dan sedang dalam emosi yang sensitif. 
Seorang anak biasanya menjadi target apabila mereka berbeda dalam hal tertentu berdasarkan pendidikan, ras, berat badan yang berlebih, memiliki kecacatan atau yang sejenisnya, agama, dan lain-lain. Mereka juga cenderung sensitif, pasif, dan berasal dari keluarga yang penuh kasih dan saling peduli (Marden, 2010). Karakteristik kepribadian cukup berperan dalam kecenderungan seseorang dalam melakukan tindakan cyberbullying. Nyatanya orang dengan harga diri yang tinggi cenderung sering berperilaku agresif untuk membuktikan dirinya lebih berkuasa daripada yang lain dan salah satu cara mempertahankan kondisi tersebut adalah dengan melakukan tindakan cyberbullying.

\section{Peran Interaksi Orangtua}

Peran Interaksi orangtua dalam mengawasi aktivitas anak berinteraksi di internet merupakan faktor yang cukup berpengaruh pada kecenderungan anak untuk terlibat dalam aksi cyberbullying. Orangtua yang tidak terlibat dalam aktivitas online anak menjadikan anak lebih rentan terlibat dalam aksi cyberbullying (Willard, 2005). Beberapa faktor resiko lainnya dari orangtua yaitu: kurangnya kehangatan dan keterlibatan orangtua, pola asuh orang tua yang terlalu permisif, kurangnya pengawasan, pendisiplinan fisik dan kasar, dan/atau model perilaku bullying yang dicontohkan (umumnya secara tidak sadar) oleh orang tua (Marden, 2010). Anak-anak yang menjadi pelaku bullying cenderung agresif dan mempunyai sedikit simpati moral dan mengalami banyak konflik dalam hubungan mereka dengan orangtuanya (Marden, 2010).

Strain

Teori strain menitikberatkan pada hubungan dimana seseorang tidak diperlakukan sebagaimana dirinya ingin diperlakukan. hal ini memiliki kecendrungan terjadinya aktivitas bullying atau cyberbullying. Dengan kata lain cyberbullying dapat terjadi karena ingin mengurangi ketegangan, membalaskan dendam, atau meringankan emosi pelaku, karena dukungan sosial dan kontrol diri yang rendah (Agnew, 1992).

Dampak cyberbullying Bagi Kesehatan, hal ini dapat menyebabkan beberapa kerusakan serius pada kesehatan secara keseluruhan. Cyberbullying dapat mempengaruhi kesehatan fisik dan mental.

a Gejala Fisik: selera makan hilang, sulit tidur atau gangguan tidur, keluhan masalah kulit, pencernaan dan jantung berdebar-debar.

b Gejala Psikologis: gelisah, depresi, Kelelahan, rasa harga diri berkurang, sulit konsentrasi, murung, menyalahkan diri sendiri, gampang marah, hingga bunuh diri (Dinkes, 2015).

Para remaja / generasi millennial yang kerap menjadi korban cyberbullying terhadap gangguan fisik dan mental dari orang sekitar, sangat rentan menghadapi berbagai masalah kesehatan dan persoalan pribadi di masa depan. hal ini akan memberikan kesulitan para remaja untuk sulit bertahan dalam pekerjaan dan cenderung memiliki hubungan sosial yang buruk.

\section{Perencanaan Community Center}

Community Center dipahami dari arti per kata yaitu Community dan Center. Community (masyarakat) merupakan bagian kelompok dari masyarakat (society) dalam lingkup yang lebih kecil, serta mereka lebih terkait oleh tempat (territorial). Sedangkan kata center berasal dari Bahasa inggris yang artinya pusat (John M, Echols dan Hassan Shadilly, kamus inggris Indonesia, 1996). Dalam konteks keterbukaan informasi publik, Community Center merupakan kumpulan individu-individu yang tergabung dalam Community Center ini memiliki hak kebebasan informasi sebagai hak asasi setiap orang. Peran dan Fungsi Community Center untuk Keterbukaan Informasi Publik secara umum dapat berwujud: 

a. Sebagai pusat informasi bagi masyarakat
b. Sebagai pusat kegiatan masyarakat
c. Sebagai pendamping masyarakat
d. Menjadi mediator antara masyarakat dan pemerintah
e. Sebagai wadah untuk mengupayakan perubahan kebijakan

Dari pemahaman tersebut dapat disimpulkan, pusat pencegahan cyberbullying adalah suatu bangunan yang digunakan sebagai tempat untuk mengedukasi yang mencakup ruang galeri dan konsultan sebagai pusat edukasi bagi kelompok masyarakat khususnya generasi milenial untuk saling bertukar pemikiran.

\section{Perencanaan Pengunjung}

Pada umumnya semua orang selalu ingin didengar dan dimengerti, oleh karena itu umumnya community center menjadi wadah sebagai dukungan, dengan mendengarkan dan merespons. Namun pada era media sosial sekarang ini membuat community center menjadi terbatasi dan jauh dari publik.

Untuk membangun ketertarikan bagi pengunjung, community center harus menjadi wadah yang dapat menghubungkan relasi antara obyek dengan community and public yang menciptakan koneksi khusus terhadap obyek dan tema community center yang relevan bagi banyak orang.

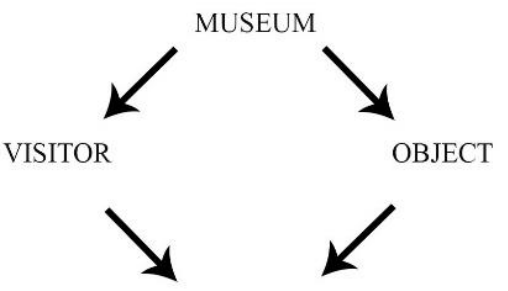

RELATION

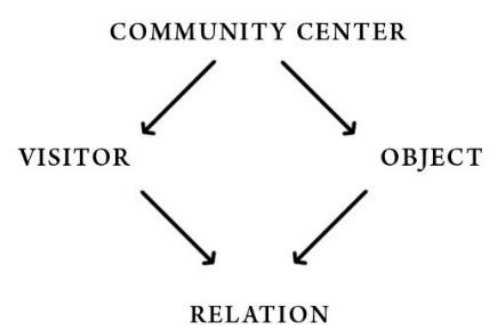

RELATION

Gambar 1. Museum dan Community Center

Sumber: The Manual of Museum Exhibition

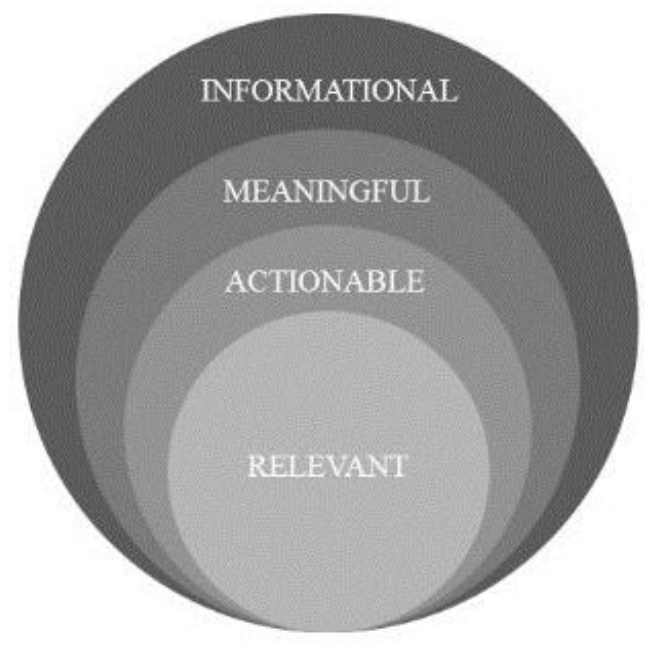

Gambar 2. Planning for Community Needs

Sumber: Manual of Museum Planning: Sustainable Space, Facilities, and Operations. 
Berikut adalah bagan yang diperlukan untuk mengetahui informasi yang didapat dari pengunjung.

a. Meaningful, sebuah informasi yang dibutuhkan bagi community, menjelaskan apa yang terpenting bagi pengunjung community center.

b. Actionable, sebagai institusi, menjelaskan pada penggunaan fungsi dari informasi yang didapat dari pengunjung.

c. Relevant, terhadap community, menjelaskan bagaimana community center dapat menghasilkan dampak dan hubungan terhadap community.

Community dan museum secara langsung berupa hubungan timbal balik yang memberikan potensi kepada dua belah pihak untuk berbagi informasi. Dimana data output dapat digunakan Community Center untuk,

a. Menyebarkan visi dan misi ke publik;

b. Meningkatkan visibilitas institusi;

c. Menjaga ekspetasi publik terhadap institusi;

d. Menarik perhatian berbagai individu dan kelompok.

Sedangkan input dari community dapat digunakan untuk,

a. Menemukan community's needs;

b. Menemukan interest, ekspetasi dan kepedulian terhadap institusi;

c. Meningkatkan interest terhadap content, storylines, themes dan koleksi yang diusulkan;

d. Mengidentifikasi peluang untuk kerjasama, kolaborasi, berbagai aktifitas dan program.

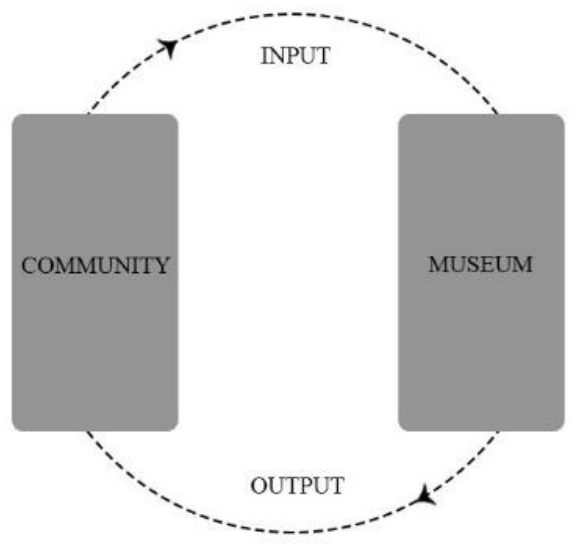

Gambar 3. Museum and it's Community

Sumber: The Manual of Museum Exhibition

Proses dalam bagan diatas merupakan usaha untuk mencapai informasi-informasi yang dikumpulkan oleh institusi dalam memastikan proses perencanaan mengarah pada project, product, atau hasil permasalahan; kerangka untuk mengikuti perkembangan yang ada.

\section{Analisa Pasar}

Dalam perencanaan community center yang sustainable, keseimbangan antara kebutuhan koleksi dan pengunjung sangat tergantung dengan visi dan misi, pencegahan dan edukasional pada community center. Fokus dalam market analysis adalah pada tren dan pasar lingkungan sekitar, untuk mencari potensi-potensi pasar pada community center.

Ada beberapa poin yang harus diperhatikan dalam merencanakan fasilitas community center yang sustainable, 
a. Ukuran dan sifat ruang publik yang paling mampu menarik pengunjung ke community center atau yang diperluas baik di jam sibuk maupun di luar jam sibuk. untuk mencakup ukuran ruang pameran, ruang kelas, sharing space, dan ruang publik terkait, tergantung pada tingkat kehadiran hasil dari analisis pasar dan perbandingan community center lain dan pemanfaatan ruang publik.

b. Ukuran dan jenis ruang publik lainnya seperti lobi, food service, retail, dan revenue generating spaces lainnya. Tujuan utamanya adalah untuk mendapatkan ukuran, kedekatan, dan fitur lainnya.

c. Pendekatan dan konsep desain, untuk mengatur tata letak community center dan konsep pada bangunan.

d. Kebutuhan ruang parkir.

Segmen pasar primer adalah penduduk, kelompok sekolah, dan turis, tetapi dalam segmen utama ini dimungkinkan untuk dapat diklasifikasikan dalam berbagai cara. Tiga metode umum segmentasi yang sesuai untuk community center adalah

a. Demographic/socioeconomic (age, gender, ethnicity, education and income);

b. Geographic and travel pattern (origin, season, mode of travel, visitor party composition);

c. Psychographic (purpose of visit, behavioral patterns, lifestyle, special interests).

\section{METODE}

Proses perancangan Pusat Pencegahan Cyberbullying ini melewati hasil analisis terhadap data-data dan teori yang dikumpulkan berdasarkan hasil penelitian dan pengamatan, serta survey dengan melakukan penyebaran angket pertanyaan kepada sejumlah orang yang berkelahiran tahun 90 -an (generasi milenial). Selain itu dalam proses perancangan juga menggunakan metode poetic of space.

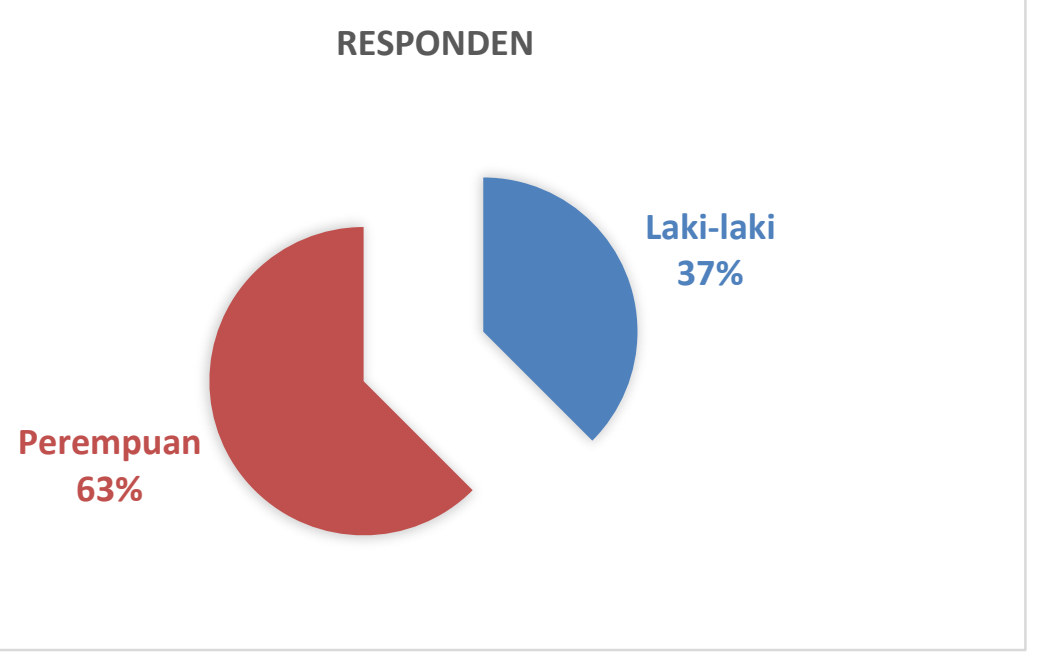

Gambar 4. Jumlah Responden

Sumber: Penulis, 2019 


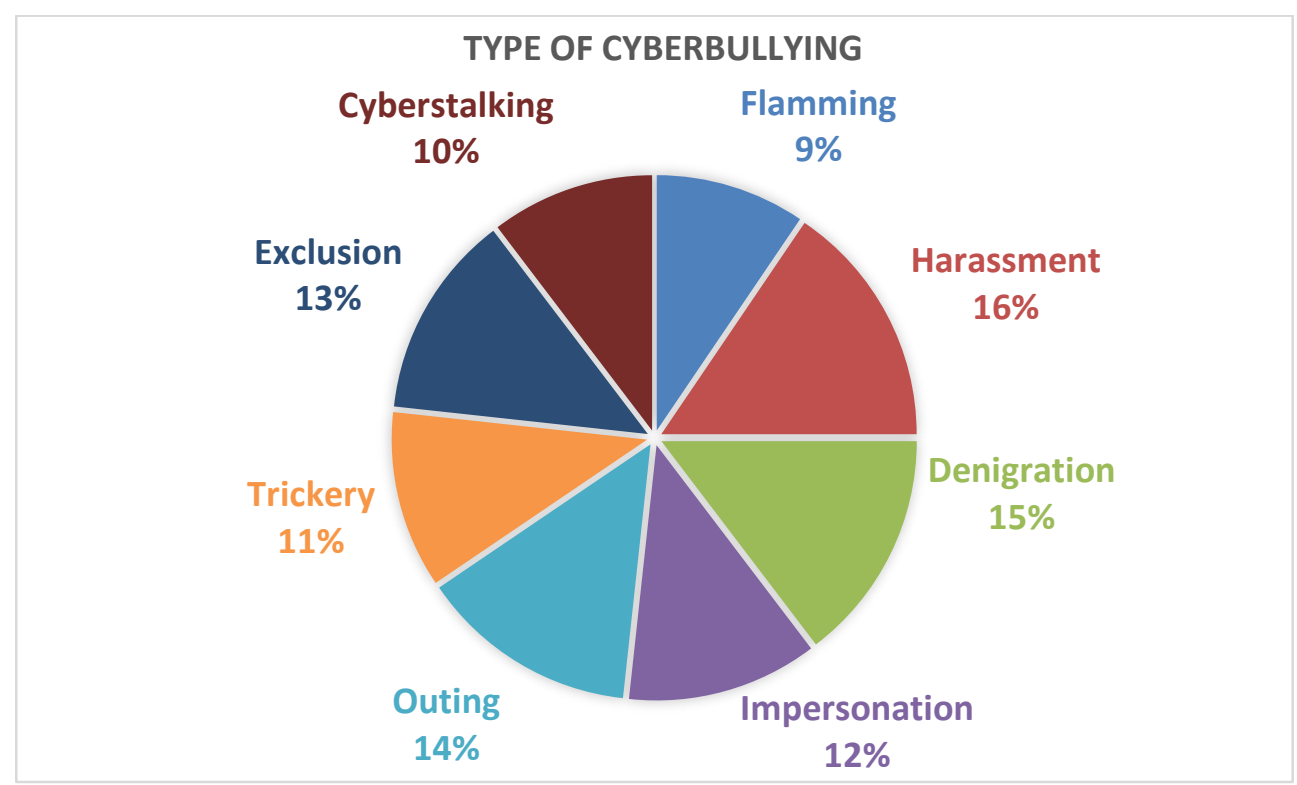

Gambar 5. Hasil Responden

Sumber: Penulis, 2019

Proses perancangan menggunakan metode poetic of space yang mengacu pada data gambar no. 5, yang disusun untuk membentuk sirkulasi dan menciptakan simulasi dampak cyberbullying pada fungsi bangunan. "Poetic as a vision of architecture" Le Corbusier, hadiah karya seni yang unik dalam arsitektur, dimana itu adalah kombinasi volume, cahaya, warna, bahan, bentuk, bahan, yang diterjemahkan ke dalam ruang. "Poetic as a sense of beauty in experiencing space" Steven Holl. Menurut Steven Holl, poetic dalam arsitektur merupakan suatu pemahaman yang logis, dimana poetic selalu terkait dan dimediasi dengan linguistik dalam pengalaman dan konteks manusia, berdasarkan dan diekspresikan melalui elemen yang berbeda seperti cahaya, bayangan, dan transparansi: warna, tekstur, bahan, dan detail semua berpartisipasi dalam pengalaman arsitektur yang lengkap.

"Poetic Detail is a relationship of texture and of construction, in nature colour, light, reflection, Surface, and in the way material are juxtaposed" Steven Holl, bahwa semua elemen arsitektur dapat terhubung untuk mengekspresikan Poetic detail. Steven Holl mengatakan dalam bukunya 'Poetic of detail ', bahwa bangunan harus memiliki daya tarik di dalamnya, atau yang disebut pengalaman ruang, melalui makna puisi.

\section{DISKUSI DAN HASIL}

Lokasi tapak berada di Jalan Griya Utama, Jakarta Utara, tepatnya berdekatan dengan jalan utama Benyamin Sueb, dan juga jalan Danau Sunter Utara; dengan luas tapak $800 \mathrm{~m}^{2}$. Berada di kawasan industri dan pergudangan dalam bentuk ruko (rumah toko), dan perumahan Sunter Agung. Dimana kawasan juga didominasi oleh kawasan perumahan . 


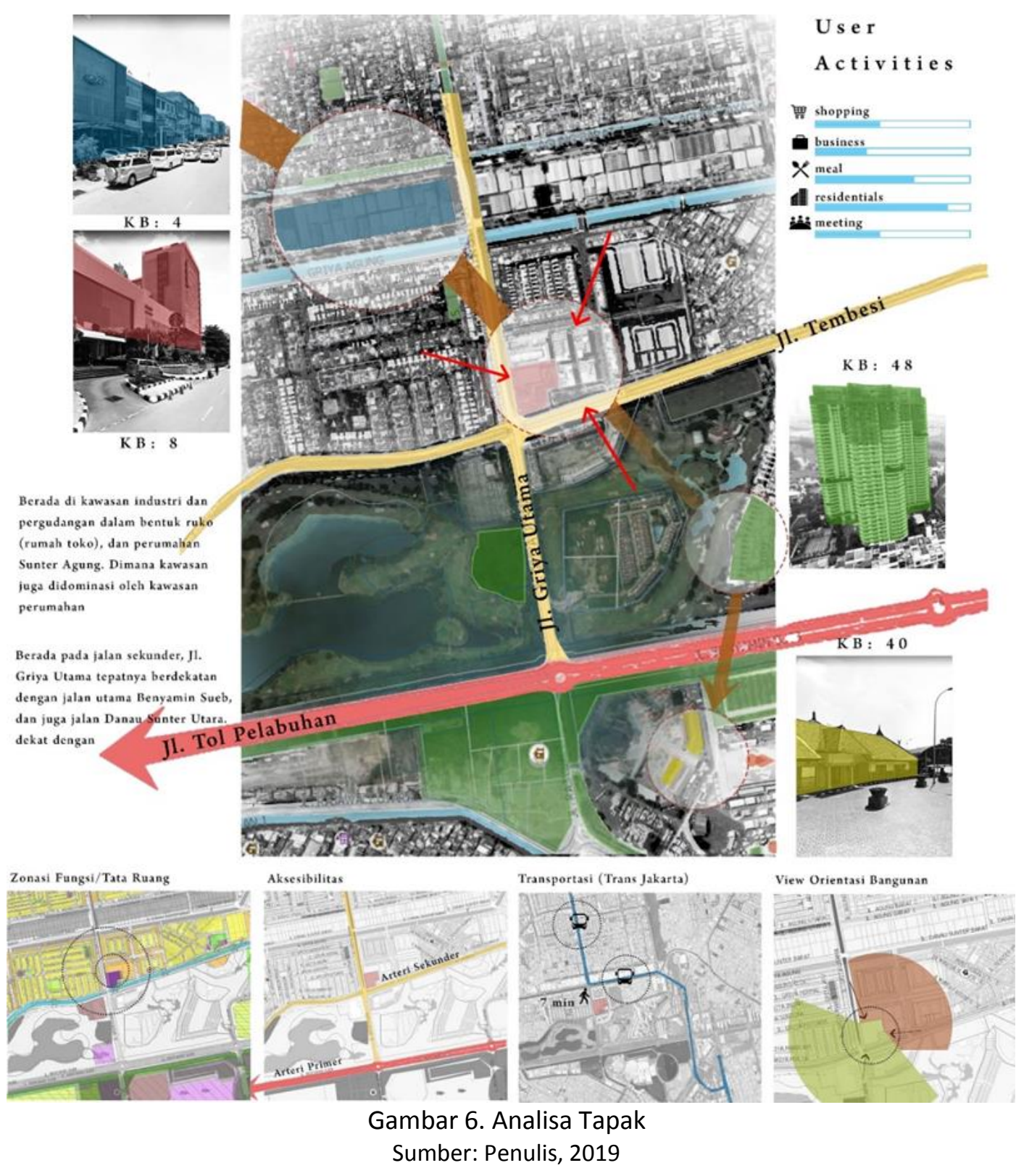

Analisa Pengunjung:

a. pengunjung pada umumnya generasi milenial (perkantoran);

b. pada malam hari umumnya pengunjung berusia tua (40an keatas);

c. Warga negara asing (daerah penginapan/hotel). 


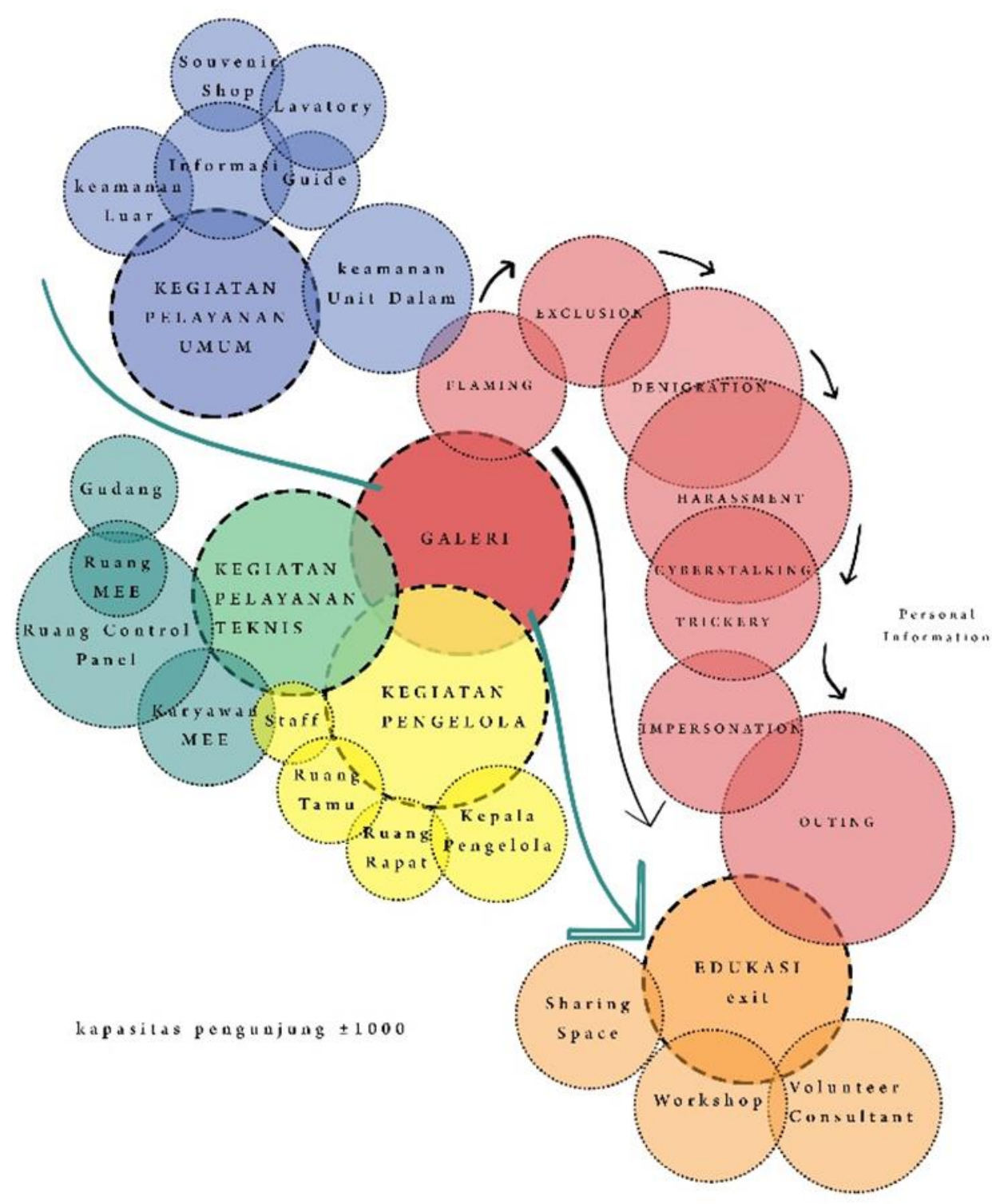

Gambar 7. Programmatik

Sumber: Penulis, 2019

Pembangunan Pusat Pencegahan Cyberbullying di Jakarta Utara, dirancang dengan menciptakan atau mengkombinasikan tipologi galeri dan museum modern yang diadaptasi dengan kebiasaan atau pendekatan dengan generasi milenial untuk menjadi sebuah community space. Penemuan tipologi baru dalam menyampaikan pesan serta menghubungkan relasi antara visi misi dan elemen-elemen arsitektur pada community space, menjadi titik utama keberhasilan bangunan. Dalam menggaet generasi milenial dan generasi selanjutnya yang jauh lebih modern untuk berkunjung; proyek ini banyak memakai visual digital dan virtual reality yang mengajak pengunjung yang berkunjung memiliki pengalaman yang interaktif dengan wahana ataupun obyek yang di pamerkan di dalamnya. 


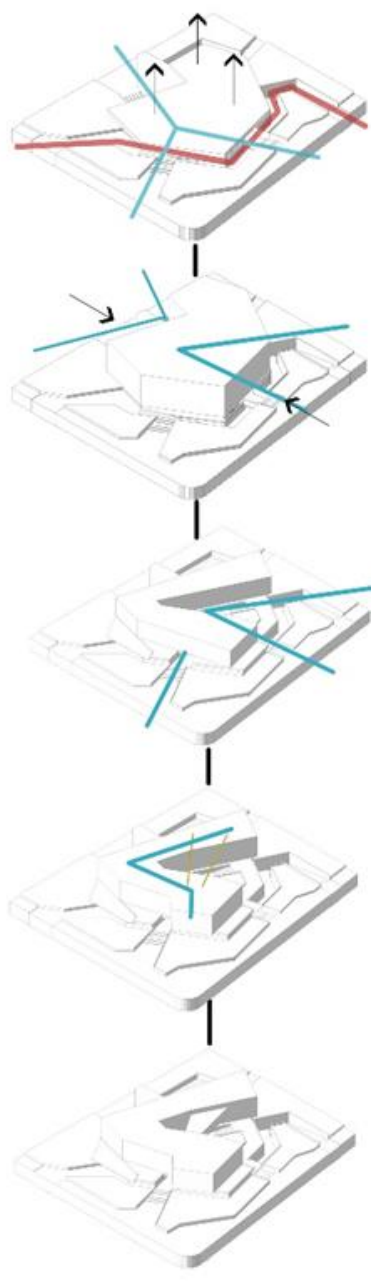

Mengedepankan sirkulasi pedestrian dengan menurunkan sirkulasi kendaraan di bawah tapak

Massa terbentuk mengikuti 3 sirkulasi pedestrian, dari arah utara, timur dan barat tapak

Orientasi massa terhadap view luar tapak yang memperlihatkan tahapan ketinggian bangunan pada kawasan kemayoran.

Membentuk sirkulasi crossing bagi pengguna, yang membentuk void pada massa tanpa menghalangi view luar tapak

Gambar 8. Design Scheme

Sumber: Penulis, 2019
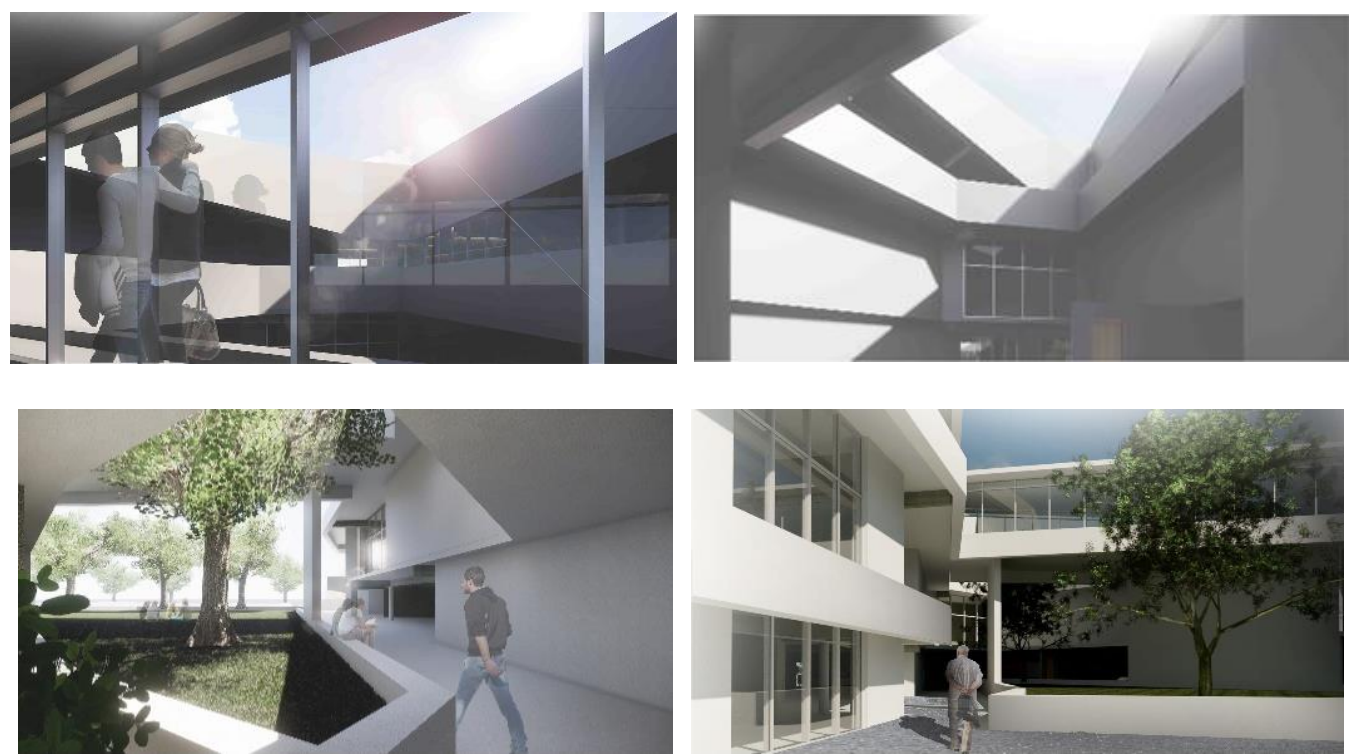

Gambar 9. Perskpektif Eksterior \& Interior

Sumber: Penulis, 2019 


\section{KESIMPULAN DAN SARAN}

Sebuah Institusi yang bertujuan untuk menciptakan lingkungan yang lebih aman bagi remaja dan orang dewasa, dan untuk meningkatkan kesadaran dan partisipasi publik dalam menanggapi dan mencegah penindasan di dunia maya. Sebagai institusi yang menawarkan konsultan sukarela untuk mendukung dan memberdayakan remaja, dan bersama-sama dengan mereka, mencari solusi tentang bagaimana menghentikan cyberbullying di lingkungan mereka. Sebagai perwujudan misinya, Cyberbullying Prevention Center ini akan menjadi wadah yang digunakan untuk merasakan situasi yang dihadapi korban cyberbullying agar dapat membangun rasa kepedulian sosial.

\section{REFERENSI}

A, J. (2015). Psikolog dari Cyberbullying, 20.

Agnew. (1992). Foundation for a general strain theory of crime and delinquency. In Criminology (pp. 30 (1), 47-48).

Barry, L., G. D. (2001). Manual of Museum Planning: Sustainable Space, Facilities, and Operations. Oxford: Rowman \& Littlefield .

Essay. (2018, November 22). How to Express Poetic in Architecture Philosophy Essay. Retrieved from Ukessays: https://www.ukessays.com/essays/philosophy/how-to-express-poetic-inarchitecture-philosophy-essay.php?vref=1

Indonesia, A. P. (2014). Jumlah pengguna Internet Indonesia.

Ingke, P. (2010). Hubungan antara peran dalam bullying tradisional dan peran dalam cyberbullying pada remaja.

Kowalski, R. L. (2008). Cyberbullying: Bullying in the digital age. Oxford: Blackwell.

Lord, B. L. (2001). The Manual of Museum Exhibition. Oxford: Rowman \& Littlefield .

Marden, N. (2010, oktober 22). Exposing The Cyberbully. Retrieved from Library: http://library.wcsu.edu/dspace/bitstream/0/526/1/ CYBERBULLYINGTHESIS_FINAL.pdf

Wikipedia. (2011, oktober 25). Bullying. Retrieved from wikipedia: http://en.wikipedia.org/wiki/ Bullying

WireKids, (. (2010, Oktober 19). Stop Cyberbullying. Retrieved from Stopcyberbullying: http:// stopcyberbullying.org

Y, C. (2014). Cyberbullying di Kalangan Remaja. Studi tentang Korban Cyberbullying di Kalangan Remaja di Surabaya, 23. 
